\title{
Pharmaceutical Characterization of MyoNovin, a Novel Skeletal Muscle Regenerator: in silico, in vitro and in vivo Studies
}

Samaa Alrushaid ${ }^{1}$, Neal M. Davies², Judy E. Anderson ${ }^{3}$, Tyson Le' ${ }^{1}$, Jaime A. Yáñez ${ }^{4}$, Zaid H. Maayah², Ayman O.S. El$\mathrm{Kadi}^{2}$, Ousama Rachid ${ }^{5}$, Casey L. Sayre ${ }^{6}$, Raimar Löbenberg ${ }^{2}$, Frank J. Burczynski ${ }^{1,7}$

${ }^{1}$ College of Pharmacy, Rady Faculty of Health Sciences, University of Manitoba, Winnipeg, MB, Canada. ${ }^{2}$ Faculty of Pharmacy and Pharmaceutical Sciences, University of Alberta, Edmonton, AB. CANADA. ${ }^{3}$ Department of Biological Sciences, Faculty of Science, and Department of Human Anatomy and Cell Science, Max Rady College of Medicine, Rady Faculty of Health Sciences, University of Manitoba, Winnipeg, Manitoba, Canada. ${ }^{4}$ YARI International Group, New Brunswick, NJ 08901 and INDETEC Corp., Lima Perú. ${ }^{5}$ Pharmaceutical Sciences Section, College of Pharmacy, Qatar University, Doha, Qatar. ${ }^{6}$ College of Pharmacy, Roseman University of Health Sciences, South Jordan. ${ }^{7}$ Department of Pharmacology \& Therapeutics, Max Rady College of Medicine, Rady Faculty of Health Sciences, University of Manitoba, Winnipeg, MB, Canada.

Received, November 23, 2017; Revised, December 5, 2015; Accepted, December 14, 2017; Published, January $18,2018$.

ABSTRACT - PURPOSE: MyoNovin is a novel skeletal muscle-regenerating compound developed through synthesis of two nitro groups onto a guaifenesin backbone to deliver nitric oxide to skeletal muscle with a potential to treat muscle atrophy. The purpose of this study was to utilize in silico, in vitro, and in vivo approaches to characterize MyoNovin and examine its safety, biodistribution, and feasibility for drug delivery. METHODS: In silico software packages were used to predict the physicochemical and biopharmaceutical properties of MyoNovin. In vitro cardiotoxicity was assessed using human cardiomyocytes (RL-14) while effects on CYP3A4 metabolic enzyme and antioxidant activity were examined using commercial kits. A novel HPLC assay was developed to measure MyoNovin concentration in serum, and delineate initial pharmacokinetic and acute toxicity after intravenous administration $(20 \mathrm{mg} / \mathrm{kg})$ to male Sprague-Dawley rats. RESULTS: MyoNovin showed relatively high lipophilicity with a $\operatorname{LogP}$ value of 3.49 , a 20 -fold higher skin permeability $\left(19.89 \mathrm{~cm} / \mathrm{s}^{*} 10^{7}\right)$ compared to guaifenesin $\left(0.66 \mathrm{~cm} / \mathrm{s}^{*} 10^{7}\right)$, and $\sim 10$-fold higher effective jejunal permeability $\left(2.24 \mathrm{~cm} / \mathrm{s}^{*} 10^{4}\right)$ compared to guaifenesin $\left(0.26 \mathrm{~cm} / \mathrm{s}^{*} 10^{4}\right)$. In vitro, MyoNovin was not cytotoxic to cardiomyocytes at concentrations below $8 \mu \mathrm{M}$ and did not inhibit CYP3A4 or show antioxidant activity. In vivo, MyoNovin had a short half-life $\left(\mathrm{t}_{1 / 2}\right)$ of $0.16 \mathrm{~h}$, and a volume of distribution $\mathrm{V}_{\mathrm{ss}}$ of $0.62 \mathrm{~L} / \mathrm{kg}$. Biomarkers of MyoNovin cardiac and renal toxicity did not differ significantly from baseline control levels. CONCLUSIONS: The predicted high lipophilicity and skin permeability of MyoNovin render it a potential candidate for transdermal administration while its favourable intestinal permeation suggests it may be suitable for oral administration. Pharmacokinetics following IV administration of MyoNovin were delineated for the first time in a rat model. Preliminary single 20 $\mathrm{mg} / \mathrm{kg}$ dose assessment of MyoNovin suggest no influence on cardiac troponin or $\beta$-N-Acetylglucosaminidase .

This article is open to POST-PUBLICATION REVIEW. Registered readers (see "For Readers") may comment by clicking on ABSTRACT on the issue's contents page.

\section{INTRODUCTION}

Skeletal muscle atrophies are characterized by loss of skeletal muscle mass due to aging, prolonged immobility, denervation, and/or other factors. To our knowledge, there is no clinically available pharmacological treatment specifically for muscle atrophy. Recent work revealed that nitric oxide (NO) plays an important role in skeletal muscle regeneration. The mechanism of regeneration involves the activation of satellite cells that are located in close proximity to the skeletal muscle fiber and are mitotically quiescent in adult muscle under normal physiological conditions. Under some conditions, however, such as mechanical stretching of muscle fibers and exercise, satellite cells are activated, resulting in their proliferation $(1,2)$. Both $\mathrm{NO}$ and hepatocyte growth factor are required for satellite cell activation $(3,4)$. NO triggers activation

Corresponding Author: F.J. Burczynski, College of Pharmacy, Rady Faculty of Health Sciences, University of Manitoba, 750 McDermot Ave. Winnipeg, Manitoba, CANADA. frank.burczynski@umanitoba.ca 
of resting satellite cells to enter the cell cycle (5) and hepatocyte growth factor also promotes satellite cell cycling by binding to the c-met receptor and enhancing cell migration by activated myogenic precursor cells (6). The activation of satellite cells, thus, contributes to skeletal muscle growth from exercise and repair following injury or disease onset $(7,8)$.

A study published by our group showed that transdermal administration of a clinically utilized nitric oxide donor, isosorbide dinitrate, to normal mice promoted satellite cell cycling as it increased DNA synthesis by $19-24 \%$ in adult muscle (9). Similarly, administration of methocarbamol produced a $28 \%$ increase in DNA synthesis. Coadministration of isosorbide dinitrate and methocarbamol had an additive effect, producing a $38 \%$ increase in DNA synthesis. Such observations led to the development of MyoNovin (1-(3,4-bisnitrooxy-butoxy)-2-methoxy-benzene) (10), a novel nitric oxide donor designed to specifically deliver NO to skeletal muscles. MyoNovin was chemically synthesized by attaching two nitro groups to guaifenesin. Guaifenesin is a mucolytic agent with muscle relaxant activity and is an active metabolite of methocarbamol. The guaifenesin backbone of MyoNovin is anticipated to act as a carrier for delivery of NO to skeletal muscle fibers, triggering satellite cell activation and ultimately muscle growth and repair (9). The same report showed that NO was released from homogenates of both liver and skeletal muscle after treatment with MyoNovin using experiments with electron paramagnetic resonance (EPR) spectroscopy. Furthermore, MyoNovin increased satellite cell activation and proliferation in normal mice as it increased DNA synthesis by $37-$ $39 \% 24 \mathrm{~h}$ after a single transdermal treatment and 40 $55 \%$ following $24 \mathrm{~h}$ of a single oral dose (9).

Given the essential role of NO in muscle regeneration, the promising results of MyoNovin efficacy both in vitro and in vivo in normal (9) and dystrophic mice (11) and the fact that there are no viable pharmacological treatments to treat muscle atrophy or promote skeletal muscle regeneration, MyoNovin could be a feasible therapeutic approach to treat conditions such as skeletal muscle injury and atrophy of various origins. MyoNovin is a relatively new chemical derivative of guaifenesin, and synthesis of MyoNovin from guaifenesin would be expected to alter the physicochemical and biopharmaceutical properties, and pharmacokinetic and toxicity profiles of the molecule. Thus, for further development of MyoNovin as a potential drug to promote muscle growth and repair, it is necessary to characterize its safety and explore its pharmacokinetics following IV administration. We, therefore, conducted the current study to determine the feasibility of MyoNovin for drug delivery and delineate preliminary pharmacokinetic and selected acute toxicity by characterizing the compound in silico, in vitro, and in vivo.

The physicochemical and biopharmaceutical properties of MyoNovin were examined for the first time utilizing in silico tools, while its effects on CYP450 enzymes, antioxidant activity, and cardiac safety were examined in vitro. Furthermore, a novel reverse-phase high-performance liquid chromatography (RP-HPLC) assay was developed to measure MyoNovin serum concentrations and to delineate its pharmacokinetics in a rat model. The cardiac toxicity of MyoNovin was assessed by examining its effects on cardiomyocytes in vitro and as measured by plasma concentrations of cardiac troponin in vivo, while renal toxicity was assessed by measuring in vivo levels of a renal toxicity biomarker, $\beta-\mathrm{N}$-acetylglucosaminidase (NAG) and urinary output $24 \mathrm{~h}$ post-dose.

\section{METHODS}

\section{Chemicals and Materials}

Methoxy-phenol (guaiacol), guaifenesin, allybromide, silver nitrate, acetone, brine, pinostrobin, PEG-400 and DMSO were purchased from Sigma (St. Louis, MO, USA). Beta-2methoxyphenoxy-lactic acid was obtained from BOC Sciences (Shirley, NY, USA). HPLC grade acetonitrile and methanol, ethyl acetate, and hexane were purchased from Fisher Scientific (Ottawa, ON, CA). Ultrapure water from a Milli-Q system (Millipore, Billerica, MA, USA) was used for the mobile phase. HPLC C18 Phenomenex Kinetex column ( $5 \mu \mathrm{m}, 250 \times 4.6 \mathrm{~mm})$, vials, inserts, and, 0.2 um nylon filter membranes were purchased from Phenomenex (Torrance, CA, USA). Sterile heparin $/ 50 \%$ dextrose catheter lock solution and blunt needles were obtained from SAI Infusion Technologies, Strategic Applications (Lake Villa, IL, USA). Cytochrome P450 kit catalogue \# P2857 was from Life Technologies (Burlington, ON, CA). Cayman antioxidant assay kit catalogue \# 709001 was purchased from Cayman Chemical (Ann Arbor, MI), cytochrome P450 kit catalogue \# P2857 was from Life Technologies (Burlington, $\mathrm{ON}$ ). 
Chemical Synthesis of MyoNovin

MyoNovin was synthesized by modifying the Wang et al procedure (9). A schematic representation of MyoNovin's synthesis is illustrated in Figure 1. To a stirred suspension of methoxy-phenol 1 (1.24 g, 0.01 $\mathrm{mol})$ in $20 \mathrm{~mL}$ of dry acetone, allyl bromide $(1.45 \mathrm{~g}$, $0.012 \mathrm{~mol}$ ) was added, and the mixture was heated overnight at $70^{\circ} \mathrm{C}$. The resulting solution was cooled to room temperature and filtered through sintered glass funnel to remove any solid residues. The filtrate was evaporated under reduced pressure to obtain 2 allyloxy-2-methoxy-benzene $(1.51 \mathrm{~g})$ as a colourless liquid. To an ice-cooled stirred solution of compound $2(1.0 \mathrm{~g} ; 6.09 \mathrm{mmol})$ in $12 \mathrm{~mL}$ of acetonitrile, silver nitrate $(0.024 \mathrm{~mol})$ was added followed by iodine $(1.56 \mathrm{~g}, 0.024 \mathrm{~mol})$. After iodine has dissolved, the reaction was refluxed for $12 \mathrm{~h}$, filtered, poured into water and extracted with ethyl acetate. The organic layer was washed with brine and evaporated under reduced pressure. The oil obtained was purified by flash chromatography (eluent from hexanes/EtOAc $10 / 1$ to $3 / 1 \mathrm{v} / \mathrm{v})$ to isolate compound $3(1.24 \mathrm{~g})$ as a yellow liquid. The chemical structure of MyoNovin was confirmed by $\mathrm{H}^{1} \mathrm{NMR} . \mathrm{H}^{1} \mathrm{NMR}\left(\mathrm{CDCl}_{3}\right): \delta=$ $3.85(\mathrm{~s}, 3 \mathrm{H}), 4.28(\mathrm{~d}, 2 \mathrm{H}, \mathrm{J}=5.2 \mathrm{~Hz}), 4.81(\mathrm{dd}, 1 \mathrm{H}, \mathrm{J}$ $=6.6 \mathrm{~Hz}, \mathrm{~J}=12.9 \mathrm{~Hz}), 4.98(\mathrm{dd}, 1 \mathrm{H}, \mathrm{J}=3.3 \mathrm{~Hz}, \mathrm{~J}=$ $12.9 \mathrm{~Hz})$, 5.56-5.64 (m, 1H), 6.87-7.08 (m, 4H).

\section{In Silico Characterization}

\section{Physicochemical and Biopharmaceutical Properties}

Gastro-Plus ${ }^{\mathrm{TM}}$, Marvin Sketch, and Virtual Computational Chemistry Laboratory Computer modelling software were utilized to predict the physicochemical properties of MyoNovin compared to its precursor guaifenesin. Portions of these results were generated by GastroPlus software (Version 9.0) provided by Simulations Plus, Inc. (Lancaster, California, USA). ADMET Predictor was used for modeling the biopharmaceutical and physicochemical as well pharmacokinetic parameters.

$\log \mathrm{P}$ and $\operatorname{LogS}$ values of MyoNovin were predicted using online computer software (VCCLAB, Virtual Computational Chemistry Laboratory) $(12,13)$. pKa, $\log \mathrm{P}, \log \mathrm{D}$ at $\mathrm{pH} 7.4$, and solubility at $\mathrm{pH} \quad 7.4$ were calculated using MarvinSketch $^{\mathrm{TM}}$ (ChemAxon Ltd., Cambridge, MA, USA), pKa and $\log \mathrm{P}$ were calculated using GastroPlus $^{\mathrm{TM}}$ (Simulations Plus, Inc., Lancaster, CA, USA).

\section{In vitro Characterization}

\section{Effect of MyoNovin on Metabolic Enzymes}

The effect of MyoNovin on CYP3A4 was examined using a CYP Vivid kit from Life Technologies following the manufacturer's instructions. The inhibitory effect of MyoNovin on CYP3A4 was compared to ketoconazole, a positive inhibitor of CYP3A4 and results expressed as \% inhibition.

\section{Antioxidant Activity of MyoNovin}

The antioxidant capacity of MyoNovin and derivatives was examined at $1,10,50$, and 100 $\mu \mathrm{g} / \mathrm{mL}$ using a commercial assay kit from Cayman Chemical following manufacture's instructions. The assay is based on the ability of the antioxidant in the sample to inhibit the oxidation of ABTS (2,2'-azinodi-[3-ethylbenzthiazoline sulphonate]) to ABTS by metmyoglobin. The amount of ABTS produced is measured at $750 \mathrm{~nm}$. Presence of antioxidants will supress absorbance at $750 \mathrm{~nm}$. Antioxidant activity of MyoNovin, guaifenesin, $\beta$ methoxy-phenoxylactic acid, and allyloxy-2-methoxy-benzene was compared to that of Trolox, a water soluble $\alpha$ tochopherol analog, and the result was expressed as molar equivalents of Trolox. Quercetin was used a positive control at 10 and $100 \mu \mathrm{g} / \mathrm{mL}$.

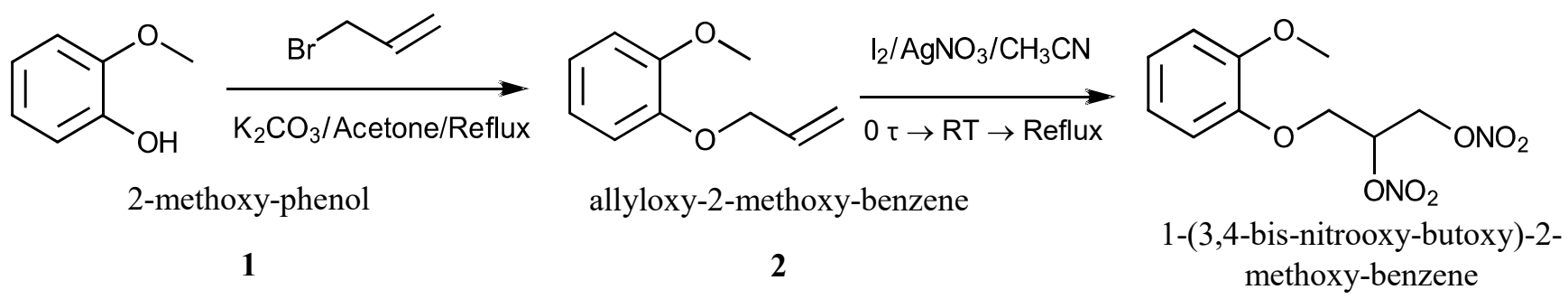

Figure 1. A schematic diagram of MyoNovin synthesis. 
Effects of MyoNovin on Human Cardiomyocytes The effect of MyoNovin on cardiac tissue was assessed using human cardiomyocytes RL-14 cells (American Type Cell Culture Patent Deposit Designation PTA-1499 Mannanas, VA, USA). Cells were grown in $75 \mathrm{~cm}^{2}$ tissue culture flasks at $37^{\circ} \mathrm{C}$ in a humidified incubator with $5 \% \mathrm{CO}_{2}$ containing $\mathrm{DMEM} / \mathrm{F}-12$, phenol red supplemented with $12.5 \%$ fetal bovine serum, $20 \mu \mathrm{M}$ L-glutamate, $100 \mathrm{IU}$ penicillin $\mathrm{G}$ and $100 \mu \mathrm{g} / \mathrm{mL}$ streptomycin. Following 3-4 days of incubation, cells were detached using trypsin and seeded on 12-well culture plates with DMEM/F-12 for $24 \mathrm{~h}$. Cells were subsequently washed with PBS, replenished with serum free media, and treated with MyoNovin at 2, 4, 8, 16, and $32 \mu \mathrm{M}$ for $24 \mathrm{~h}$. Effects of MyoNovin on RL-14 viability were determined using MTT (3-(4,5dimethylthiazol-2-yl)-2,5-diphenyltetrazolium bromide) assay. The assay measures the capacity of cells to convert MTT to coloured formazan crystals, as described previously $(14,15)$.

\section{HPLC Analysis of MyoNovin}

The Shimadzu HPLC system (Kyoto, Japan) consisting of LC-20AB prominence liquid chromatograph, SIL-10AF auto-injector, SPD-10AV UV-VIS detector, and SCL-10A system controller was used for analysis. Separation was achieved using a C18 Phenomenex Kinetex column $(5 \mu \mathrm{m}, 250$ x 4.6 $\mathrm{mm}$ ) with UV detection at $275 \mathrm{~nm}$. The mobile phase was prepared by mixing acetonitrile:water:methanol $(75: 20: 5 \mathrm{v} / \mathrm{v})$, filtered through a $0.2 \mathrm{um}$ nylon filter and degassed using reduced pressure prior to use. Separation was carried out isocratically at ambient temperature $\left(22 \pm 1^{\circ} \mathrm{C}\right)$ with a flow rate of 0.6 $\mathrm{mL} / \mathrm{min}$. Pinostrobin was used as the internal standard. Shimadzu EZStart (Version 7.4) software was used for data acquisition and integration. Samples were freshly prepared on day of analysis and injected into the HPLC system.

\section{Preparation of Standard Solutions}

Stock solutions of MyoNovin $(10 \mathrm{mg} / \mathrm{mL})$ and the internal standard pinostrobin $(1 \mathrm{mg} / \mathrm{mL})$ were prepared in DMSO, protected from light, and stored at $-20^{\circ} \mathrm{C}$. Working solutions were freshly prepared in DMSO to obtain a final concentration of $0.5,1.0$, 10.0 , and $100 \mu \mathrm{g} / \mathrm{mL}$ in rat serum or urine. Standard solutions of MyoNovin were prepared by spiking MyoNovin $(0.5-100 \mu \mathrm{g} / \mathrm{mL})$ and pinostrobin (10 $\mu \mathrm{g} / \mathrm{mL})$ in $100 \mu \mathrm{l}$ of blank rat serum or urine. The final concentration of DMSO in spiked standards of serum and urine samples did not exceed 3\%.

\section{Calibration Curves}

Calibration curves were constructed by plotting the peak area ratio of MyoNovin to the internal standard (pinostrobin) versus calibration standard concentrations of MyoNovin, respectively.

\section{Linearity, Lower Limit of Quantification, and Lower Limit of Detection}

Linearity was assessed based on the coefficient of determination $\left(\mathrm{r}^{2}\right)$ of the calibration curve using unweighted least squares linear regression. The lower limit of quantitation (LOQ) was determined based on the lowest concentration that showed a \pm $15 \%$ difference between the actual added concentration and the average calculated concentration. The lower limit of detection (LOD) was estimated by comparing signals of known low concentrations of MyoNovin spiked in serum to blank serum samples without MyoNovin. The concentration of MyoNovin with a 1:3 signal to noise ratio was considered the lower limit of the analytical assay.

\section{Accuracy, Precision and Recovery}

The analytical method was evaluated by calculating the intra-day variation of spiked MyoNovin standards in rat serum. The intra-day variation was determined by comparing 5 replicates of different concentrations of MyoNovin (5, 10, 25, 50, and 100 $\mu \mathrm{g} / \mathrm{mL}$ ) spiked in serum on 5 days in a 1 -week period. Calibration curves were established each day. Precision was evaluated using Coefficient of Variance $\left(\mathrm{CV}=\mathrm{SD} / \mathrm{C}_{\text {average }}\right)$ where $\mathrm{SD}$ is the standard deviation and $\mathrm{C}_{\text {average }}$ is the mean calculated concentration of five replicates. Accuracy was assessed by comparing the percentage error of calculated concentration to the actual concentration added using the equation $\mathrm{Bias}=\left(\mathrm{C}_{\text {calculated }}{ }^{-}\right.$ $\mathrm{C}_{\text {theoretical }} / \mathrm{C}_{\text {theoretical; }}$ where $\mathrm{C}_{\text {calculated }}$ is the concentration calculated from calibration curve and $\mathrm{C}_{\text {theoretical }}$ is the actual concentration added (16).

Percent recovery was determined by comparing peak area ratios of MyoNovin to the internal standard (pinostrobin) after extracting MyoNovin from serum-spiked samples to respective samples spiked in the mobile phase without extraction. 


\section{In vivo Characterization}

This study was approved by the Bannatyne Campus Animal Care Committee at the University of Manitoba (protocol \#16-004) in conformity with the Canadian Council on Animal Care guidelines. Male $\mathrm{CD}^{\circledR}$ Sprague-Dawley rats (average weight: $250 \pm 25$ g) were obtained with the jugular vein surgically cannulated using polyurethane-silastic blended catheters from Charles River Labs (St. Constant, QC, Canada). Rats were housed individually in temperature-controlled rooms with a $12 \mathrm{~h}$ light/dark cycle. All animals had free access to Purina Rat Chow (5001) and water, except when specified below. Animals were acclimatized in standard cages with environmental enrichment for a minimum of 3 days prior to commencing the pharmacokinetic study.

\section{Pharmacokinetic Study}

Jugular cannulas in 5 rats were flushed daily with a sterile heparin $/ 50 \%$ dextrose catheter lock solution to maintain the patency as advised in the technical bulletin supplied with the animals from Charles River (17). Each animal was placed in a separate metabolic cage overnight and fasted overnight (12 h) before drug administration (IV; $20 \mathrm{mg}$ MyoNovin $/ \mathrm{kg}$ $\mathrm{BW})$. The dose was selected based on our previous study whereby mice received a single oral dose of 80 $\mathrm{mg} / \mathrm{kg}$ (9). MyoNovin was freshly reconstituted in $3 \%$ DMSO and 97\% PEG-400 prior to dosing. Animals received water ad libitum pre- and postdosing. Food was provided 2 hours post-dosing. Serial blood samples $(0.30 \mathrm{~mL}$ each $)$ were collected at $0,1,5,15$, and $30 \mathrm{~min}$, followed by $1,2,4,6,12$, and $24 \mathrm{~h}$ after IV drug administration. At $24 \mathrm{~h}$ following drug administration, animals were euthanized and exsanguinated. Immediately after all blood-collection time points (except the terminal point), the cannula was flushed with the same volume of $0.9 \%$ saline to replenish the collected blood volume. The dead volume of the cannula was filled with a small volume $(\sim 0.15 \mathrm{~mL})$ of heparinized lock solution after each blood draw to maintain the patency of the cannula. Blood samples were collected in polypropylene microcentrifuge tubes and centrifuged at 15,000 rpm for 5 min (Beckman Microfuge centrifuge, Beckman Coulter Inc., Fullerton, CA, USA) to collect serum. Serum was stored at $-20^{\circ} \mathrm{C}$ until sample preparation for HPLC drug analysis. Urine samples were also collected from metabolic cages at $0,2,6,12$, and $24 \mathrm{~h}$ following MyoNovin administration. The exact urine volume of each sample was recorded and urine stored at $-20^{\circ} \mathrm{C}$ until preparation for HPLC drug analysis.

\section{Treatment of Serum Samples for Analysis}

Pinostrobin $(10 \mu \mathrm{g} / \mathrm{mL}$ final concentration) was added to $120 \mu \mathrm{L}$ of all serum samples with the exception of the $0 \mathrm{~h}$ sample. Samples were vortexed for 1 min using a Vortex Genie-2 (VWR Scientific, West Chester, PA). One (1.0) $\mathrm{mL}$ of cold HPLC grade acetonitrile (pre-stored at $-20^{\circ} \mathrm{C}$ ) was added to samples to precipitate plasma proteins, vortexed for 5 min (Vortex Genie-2, VWR Scientific), and centrifuged at 15,000 rpm for $15 \mathrm{~min}$ before the supernatant was transferred to new, labeled $2 \mathrm{~mL}$ centrifuge tubes. Samples were evaporated to dryness using a Savant SPD1010 SpeedVac Concentrator without heat (Thermo Fisher Scientific, Inc., Asheville, NC). The residue was reconstituted with $100 \mu \mathrm{L}$ of mobile phase, vortexed for $1 \mathrm{~min}$ and centrifuged at 15,000 rpm for $5 \mathrm{~min}$; the supernatant was transferred to HPLC vials and $120 \mu \mathrm{L}$ was injected into the HPLC system.

\section{Pharmacokinetic Analysis}

Pharmacokinetic analysis was performed using data from individual rats, and the mean and standard error of the mean (SEM) calculated for each group. The elimination rate constant $\left(\mathrm{k}_{\mathrm{el}}\right)$ was estimated by linear regression of serum concentration in the loglinear terminal phase. A non-compartmental model was fitted to the data for serum concentration versus time using Phoenix WinNonlin software Ver. 6.3 (Pharsight Corporation, Mountain View, CA) to calculate the pharmacokinetic parameters in the terminal phase, namely mean residence time (MRT), total clearance $\left(\mathrm{CL}_{\mathrm{tot}}\right)$, and volume of distribution $\left(\mathrm{V}_{\mathrm{ss}}\right)$. The initial maximum serum concentration $\left(\mathrm{C}_{0}\right)$ was calculated by back extrapolation using Phoenix WinNonlin software.

\section{Renal Assessment}

\section{Effects on urinary output}

The urinary output of rats over $24 \mathrm{~h}$ was monitored just before (24 h pre-dose period) and after administration of a single IV dose of MyoNovin (20 $\mathrm{mg} / \mathrm{kg} ; 24 \mathrm{~h}$ post-dose period). Acute renal toxicity induced by any drug may result in a reduced total urinary output (18). The total urine volume excreted over $24 \mathrm{~h}$ post-dosing was compared to the total urine volume excreted over the $24 \mathrm{~h}$ pre-dosing. 
$\beta$-N-Acetylglucosaminidase (NAG) NAG is a lysosomal enzyme found at high concentration in kidney tubule cells. Appearance of NAG in the urine is used as a sensitive, early marker of renal damage (19). Urine samples $(100 \mu \mathrm{l})$ from pharmacokinetic studies after a single IV dose of MyoNovin collected at $0,2,6,12$, and $24 \mathrm{~h}$ were analyzed to determine NAG concentrations without dilution on a Medica EasyRa automated clinical chemistry analyzer (Medica Corporation Bedford, MA) (20). Cumulative amounts of NAG excreted in the urine over the $24 \mathrm{~h}$ post-dosing with MyoNovin were compared to cumulative amounts pre-dosing to assess renal toxicity.

\section{Assessment of Cardiac Toxicity}

The potential cardiac toxicity of MyoNovin was also assessed in vivo utilizing a rat cardiac Troponin-I (cTnI) ultra-sensitive ELISA kit assay from Life Diagnostics, Inc. (West Chester, PA, USA). Blood samples from pharmacokinetic studies were collected at $24 \mathrm{~h}$ from the jugular vein after a single $20 \mathrm{mg} / \mathrm{kg}$ IV dose $(\mathrm{n}=4)$. Samples were centrifuged to obtain serum and stored at $-20^{\circ} \mathrm{C}$ until analysis. On the day of analysis, cTnI concentrations were measured in serum samples following manufacturer's instructions.

\section{STATISTICAL ANALYSIS}

Compiled data were presented as mean and standard error of the mean (mean \pm SEM) unless otherwise stated. Where possible, data were analyzed for statistical significance using SigmaPlot software (v. 13.0, Systat Software, Inc., San Jose, CA). Student's t-tests were employed for unpaired samples to compare means between two groups, while one-way ANOVAs were employed to compare the means of three or more groups followed by Tukey-Kramer multiple comparison Test between groups if necessary. A p-value less than 0.05 was considered statistically significant.

\section{RESULTS}

\section{In silico Characterization}

The physiochemical and biopharmaceutical properties of MyoNovin were compared to those of its parent compound, guaifenesin. MyoNovin had a lower predicted water solubility and higher $\log P$ value compared to guaifenesin (Table 1), indicating higher lipophilicity. The $\mathrm{pH}$-solubility profile of
MyoNovin (Figure 2A) shows that the solubility of MyoNovin is not affected by changes in $\mathrm{pH}$, while the solubility of guaifenesin increased at $\mathrm{pH}>12$ (Figure 2B). Examination of the solubility of MyoNovin in simulated gastric and gastrointestinal fluids revealed that MyoNovin has a 1000-fold lower predicted solubility in the fasted state in simulated gastric fluid $(0.004 \mathrm{mg} / \mathrm{mL})$ compared to guaifenesin $(4.574 \mathrm{mg} / \mathrm{mL})$ (Figure 3). The predicted solubility of MyoNovin in simulated intestinal fluid in the fed state $(0.756 \mathrm{mg} / \mathrm{mL})$ was more than 30 -fold higher than in the fasted state $(0.022 \mathrm{mg} / \mathrm{mL})$, suggesting better oral absorption of MyoNovin would be achieved when it is administered with food. Interestingly, prediction of guaifenesin solubility in simulated intestinal fluid showed that its solubility is higher in fasted state $(2.085 \mathrm{mg} / \mathrm{mL})$ compared to that in the fed state $(0.272 \mathrm{mg} / \mathrm{mL})$.

Predicting transmembrane permeability of MyoNovin across skin and the intestine using ADMET predictor ${ }^{\mathrm{TM}}$ software showed that MyoNovin is expected to have a 20 -fold higher skin permeability $\left(19.89 \mathrm{~cm} / \mathrm{s}^{*} 10^{7}\right)$ compared to guaifenesin $\left(0.66 \mathrm{~cm} / \mathrm{s}^{*} 10^{7}\right)$ and approximately 10 fold higher effective jejunal permeability $(2.24$ $\left.\mathrm{cm} / \mathrm{s}^{*} 10^{4}\right)$ than guaifenesin $\left(0.26 \mathrm{~cm} / \mathrm{s}^{*} 10^{4}\right)$ (Figure 4). Moreover, prediction of MyoNovin's permeability across Madin-Darbey Canine Kidney (MDCK) cells, epithelial cells of kidney origin and commonly used for screening permeability of investigational compounds in drug discovery, is expected to be $\left(554.691 \mathrm{~cm} / \mathrm{s}^{*} 10^{4}\right) 70$-fold higher than guaifenesin $\left(7.827 \mathrm{~cm} / \mathrm{s}^{*} 10^{4}\right)$. The prediction suggests that MyoNovin likely has a useful potential to be absorbed through skin and traverse the intestine barrier. Additionally, MyoNovin appeared to be neither a substrate nor an inhibitor of P-glycoprotein (P-gp), a membrane transporter highly expressed in intestinal and renal epithelium and responsible for efflux of many xenobiotics (e.g., chemotherapeutic drugs), as shown in Table 2.

The predicted effects of MyoNovin on metabolic enzymes, calculated using ADMET Predictor $^{\mathrm{TM}}$ software, showed that MyoNovin is expected to act as a substrate of CYP3A4 and as an inhibitor of CYP1A2 (Table 2). As well, MyoNovin is expected to be $\sim 90 \%$ bound to plasma proteins as opposed $\sim 82 \%$ for guaifenesin (Table 3 ). The predicted volume of distribution for MyoNovin was 0.389 $\mathrm{L} / \mathrm{kg}$, which is about 30 -fold smaller than that of guaifenesin $(11.980 \mathrm{~L} / \mathrm{kg})$. 


\section{In vitro Characterization}

\section{Effect of MyoNovin on CYP3A4}

The effect of MyoNovin on CYP3A4 inhibition was examined utilizing a commercial assay kit.
MyoNovin did not inhibit CYP3A4 at concentrations between 0.01-50 $\mu \mathrm{M}$ (Figure 5). Only at $100 \mu \mathrm{M}$ did MyoNovin show inhibition of CYP3A4 (30\%).

Table 1. Physicochemical properties of MyoNovin and guaifenesin predicted by software packages.

\begin{tabular}{|c|c|c|}
\hline Compound & MyoNovin & Guaifenesin \\
\hline Structure & ON & Or \\
\hline Molecular Weight $(\mathrm{g} / \mathrm{mol})$ & 288.212 & 198.218 \\
\hline Formula & $\mathrm{C} 10 \mathrm{H} 12 \mathrm{~N} 2 \mathrm{O} 8$ & $\mathrm{C} 10 \mathrm{H} 14 \mathrm{O} 4$ \\
\hline pKa (MarvinSketch) & No ionisable atoms & $13.62,15.56$ \\
\hline pKa (GastroPlus) & No ionisable atoms & No ionisable atoms \\
\hline pKa (GastroPlus, after fitting solubility) & No ionisable atoms & No ionisable atoms \\
\hline $\log \mathrm{P}($ MarvinSketch) & 2.19 & 0.34 \\
\hline $\log \mathrm{P}$ (neutral, GastroPlus) & 3.49 & 0.59 \\
\hline $\log \mathrm{P}(\mathrm{VCCLAB})$ & $2.01 \pm 0.94$ & $0.67 \pm 0.38$ \\
\hline LogP (ADMET Predictor, neural) & 3.489 & 0.494 \\
\hline logD7.4 (MarvinSketch) & 2.187 & 0.337 \\
\hline Solubility at pH 7.4 (MarvinSketch) & $-3.67 \log S$ & $-1.25 \log \mathrm{S}$ \\
\hline Solubility at $\mathrm{pH} 7.4$ (MarvinSketch) & $0.0616 \mathrm{mg} / \mathrm{mL}$ & $11.15 \mathrm{mg} / \mathrm{mL}$ \\
\hline $\operatorname{logS}(\mathrm{VCCLAB})$ & -2.44 & -1.22 \\
\hline
\end{tabular}
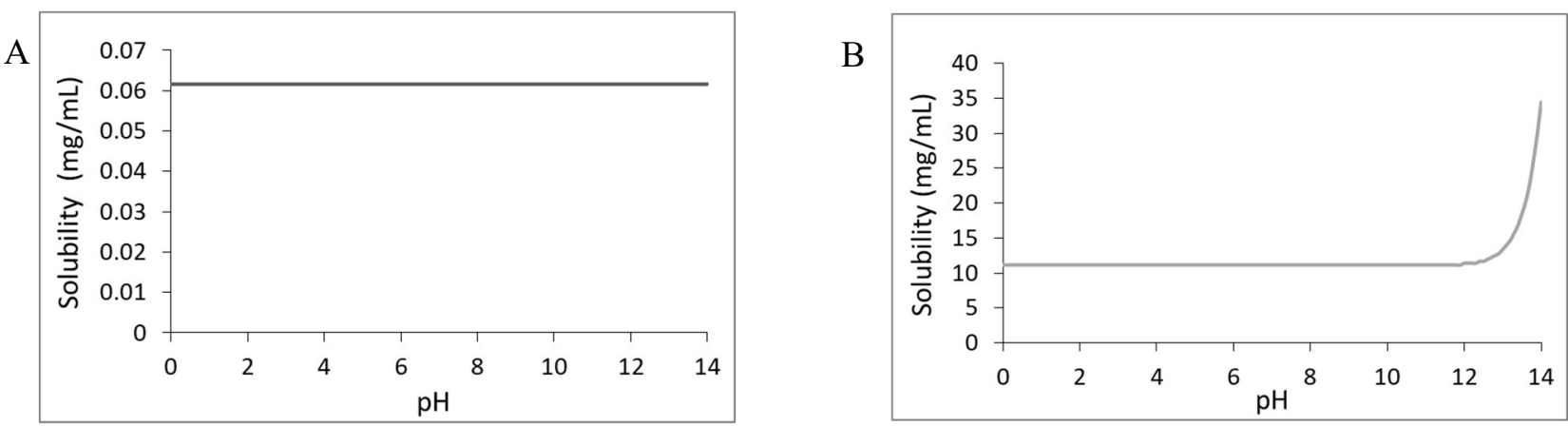

Figure 2. pH-solubility profile of (A) MyoNovin and (B) guaifenesin predicted by Marvin Sketch.

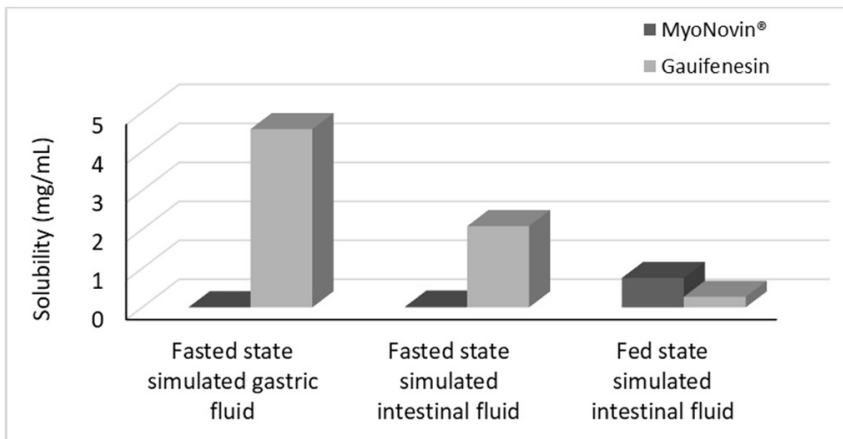

Figure 3. Predicted solubility of MyoNovin and guaifenesin in human simulated gastrointestinal fluids as calculated by ADMET Predictor software. 
Table 2. Biopharmaceutical properties of MyoNovin and guaifenesin predicted by ADMET Predictor software.

\begin{tabular}{lll}
\hline Compound & MyoNovin & Guaifenesin \\
\hline Diffusion coefficient $\left(\mathrm{cm}^{2} / \mathrm{s}^{*} 10^{5}\right)$ & 0.856 & 0.569 \\
P-gp Substrate (likelihoood of intestinal efflux by P-gp) & No $(95 \%)$ & Yes $(91 \%)$ \\
P-gp Inhibition (intestinal) & No $(94 \%)$ & No $(72 \%)$ \\
OATP1B1 Inhibition (hepatic) & No $(97 \%)$ & No $(87 \%)$ \\
CYP3A4 Inhibition & No & No+ \\
CYP3A4 Substrate & Yes & No+ \\
CYP1A2 Inhibition & Yes $(96 \%)$ & Yes $(60 \%)^{+}$ \\
CYP1A2 Substrate & No $(83 \%)$ & NA \\
CYP2D6 Inhibition & No $(95 \%)$ & No+ \\
CYP2D6 Substrate & No $(96 \%)$ & No $(85 \%)+$ \\
\hline
\end{tabular}
+www.Drugbank.ca (21), NA=not available

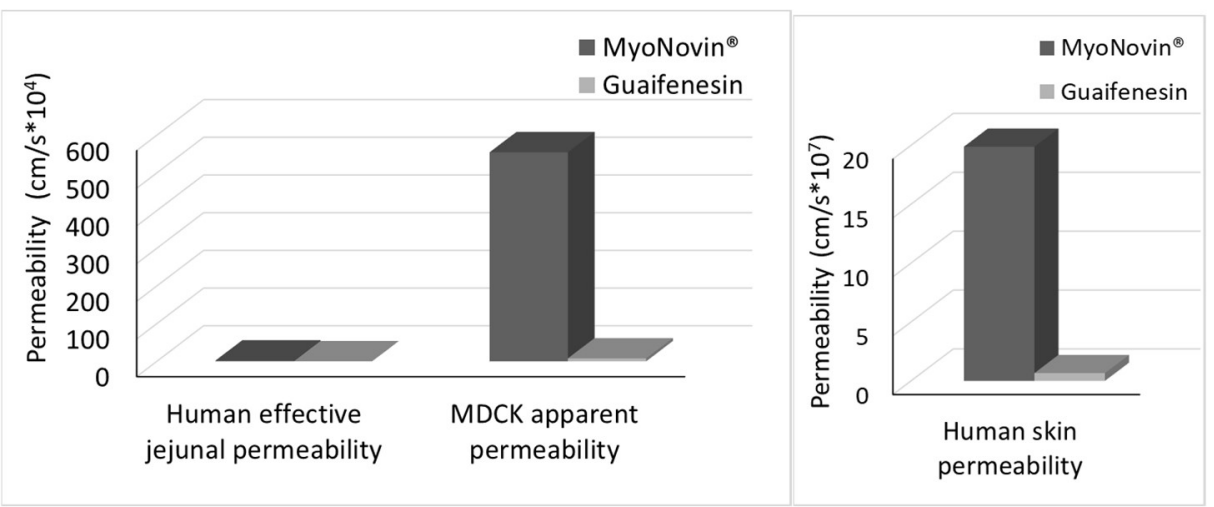

Figure 4. Predicted human intestinal and skin permeability of MyoNovin and guaifenesin, and predicted permeability across MDCK (canine origin) using ADMET Predictor software.

Table 3. Human pharmacokinetic models of MyoNovin and guaifenesin predicted using ADMET Predictor software.

\begin{tabular}{lll}
\hline Compound & MyoNovin & Guaifenesin \\
\hline Human plasma protein binding (\%unbound) & 9.994 & 22.099 \\
Human volume of distribution (Vd) & 0.389 & 11.980 \\
Blood-to-plasma concentration ratio (RBP) & 0.890 & 0.869 \\
Fraction unbound in human liver microsomes (S+fumic) & 0.394 & 0.903 \\
\hline
\end{tabular}

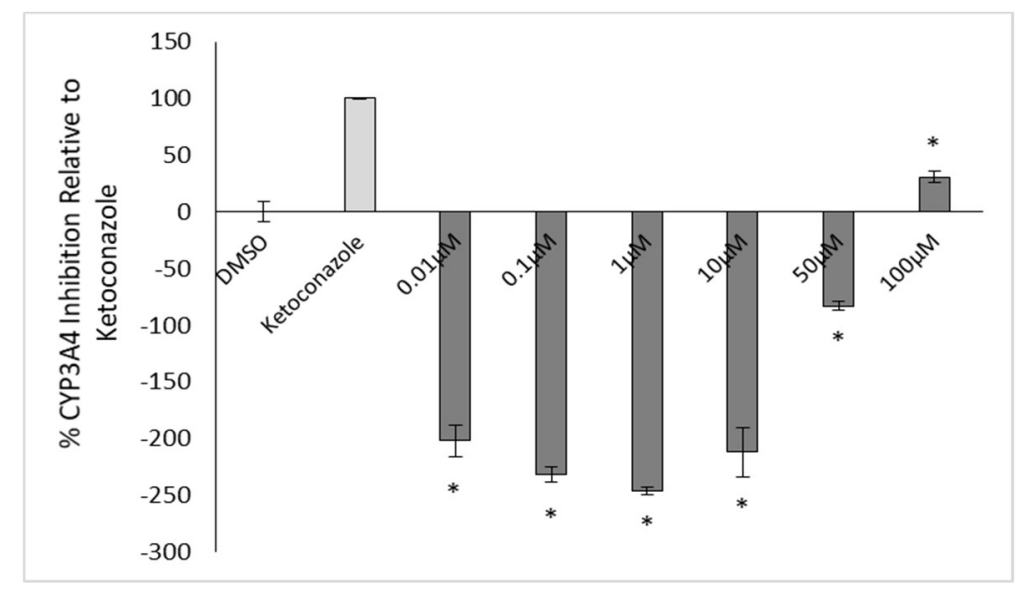

Figure 5. Percent (\%) CYP3A4 enzyme inhibition by MyoNovin ( $\mathrm{n}=4$; mean \pm SEM) expressed as $\%$ of the positive inhibitor (ketoconazole $10 \mu \mathrm{M}$ ). The concentration of DMSO did not exceed $0.1 \%$ in each well. ${ }^{*} \mathrm{P}<0.05$ compared to ketoconazole 
Antioxidant Activity

Nitric oxide exhibits anti-oxidant activity (22) by acting as a scavenger of reactive oxygen species. Thus, the antioxidant capacity of MyoNovin was examined in vitro. The result in Figure 6 shows that there is no difference in the antioxidant activity of MyoNovin or its derivatives at $1,10,50$, and 100 $\mu \mathrm{g} / \mathrm{mL}$ compared to baseline, suggesting that MyoNovin and derivatives do not exhibit antioxidant activity using this assay. However, a significant difference in the antioxidant activity was observed between MyoNovin and its derivatives compared to quercetin, which is a potent antioxidant.

\section{Effects on Human Cardiomyocytes (RL-14)}

The effects of MyoNovin on human cardiomyocytes was investigated after treatment (from 2-32 $\mu \mathrm{M}$ ) for $24 \mathrm{~h}$ by the MTT assay. Figure 7 shows that the viability of RL-14 cells at $4 \mu \mathrm{M}$ MyoNovin was $\sim 94 \%$; since this was not statistically different from the untreated control cells, the finding indicated that MyoNovin is likely non-toxic to cardiomyocytes at concentrations up to $4 \mu \mathrm{M}$. At $8 \mu \mathrm{M}$ cell viability was only about $78 \%$, significantly lower than controls, suggesting that MyoNovin did induce some cardiotoxicity resulting in $\sim 22 \%$ cell death.

\section{HPLC Analysis of MyoNovin (Analytical method development and validation)}

A RP-HPLC assay was developed to quantitate MyoNovin in serum and urine samples collected during pharmacokinetics experiments. Optimal separation between MyoNovin and the internal standard, pinostrobin, was achieved using the chromatography conditions described in methods. Chromatograms were free from peaks that co-eluted with the peaks of interest. Retention times of MyoNovin and pinostrobin were 6.2 and $7.5 \mathrm{~min}$, respectively (Figure 8). The acceptance criteria for the analytical method were in accordance with Food and Drug Administration (FDA) guidelines 23).

\section{Linearity, $L O Q$, and $L O D$}

Calibration curves of MyoNovin showed excellent linearity and a coefficient of determination $\left(\mathrm{r}^{2}\right)$ of 0.99 over the range of $0.5-100 \mu \mathrm{g} / \mathrm{mL}$. The LOQ was $5 \mu \mathrm{g} / \mathrm{mL}$ with corresponding CV of $13.21 \%$ and bias of $-10.75 \%$ (Table 4 ). The LOD was determined to be $1 \mu \mathrm{g} / \mathrm{mL}$, based on a 1:3 signal-to-noise ratio.

\section{Accuracy, Precision and Recovery}

The intra-day precision from five runs during one week showed that the assay CV\% was $<15 \%$ at the lowest concentration and $<2 \%$ at the highest concentration (Table 4). The percent bias was $10.75 \%(\mathrm{CV}=13.21 \%)$ and $-2.63(\mathrm{CV}=1.22 \%)$ at 5 and $100 \mu \mathrm{g} / \mathrm{mL}$, respectively. Percent recovery was $105 \%$ at the lower limit of quantification and $97 \%$ at $100 \mu \mathrm{g} / \mathrm{mL}$ MyoNovin. The results show that intraday coefficient of variance and bias intra-day variation were both below $15 \%$ at $5 \mu \mathrm{g} / \mathrm{mL}$ and within $\pm 5 \%$ over the range of $10-100 \mu \mathrm{g} / \mathrm{mL}$ while the percent recovery was $>97 \%$. These parameters indicated that the analytical method was sensitive, accurate and reproducible.

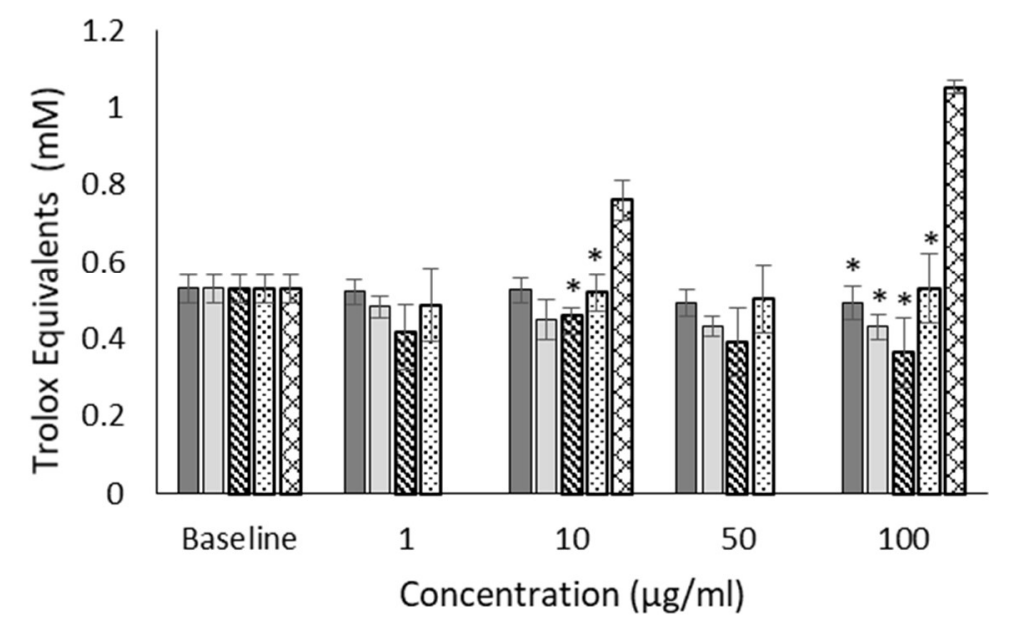

$\square$ MyoNovin $^{\circledR}$

$\square$ Guaifenesin

\$ $\beta$-Methoxyphenoxy-lactic acid

Allyloxy-2-methoxy-benzene

Q Quercetin

Figure 6. Antioxidant activity of MyoNovin and its derivatives ( $\mathrm{n}=4 \pm \mathrm{SEM}) .{ }^{*} \mathrm{P}<0.05$ compared to quercetin. 


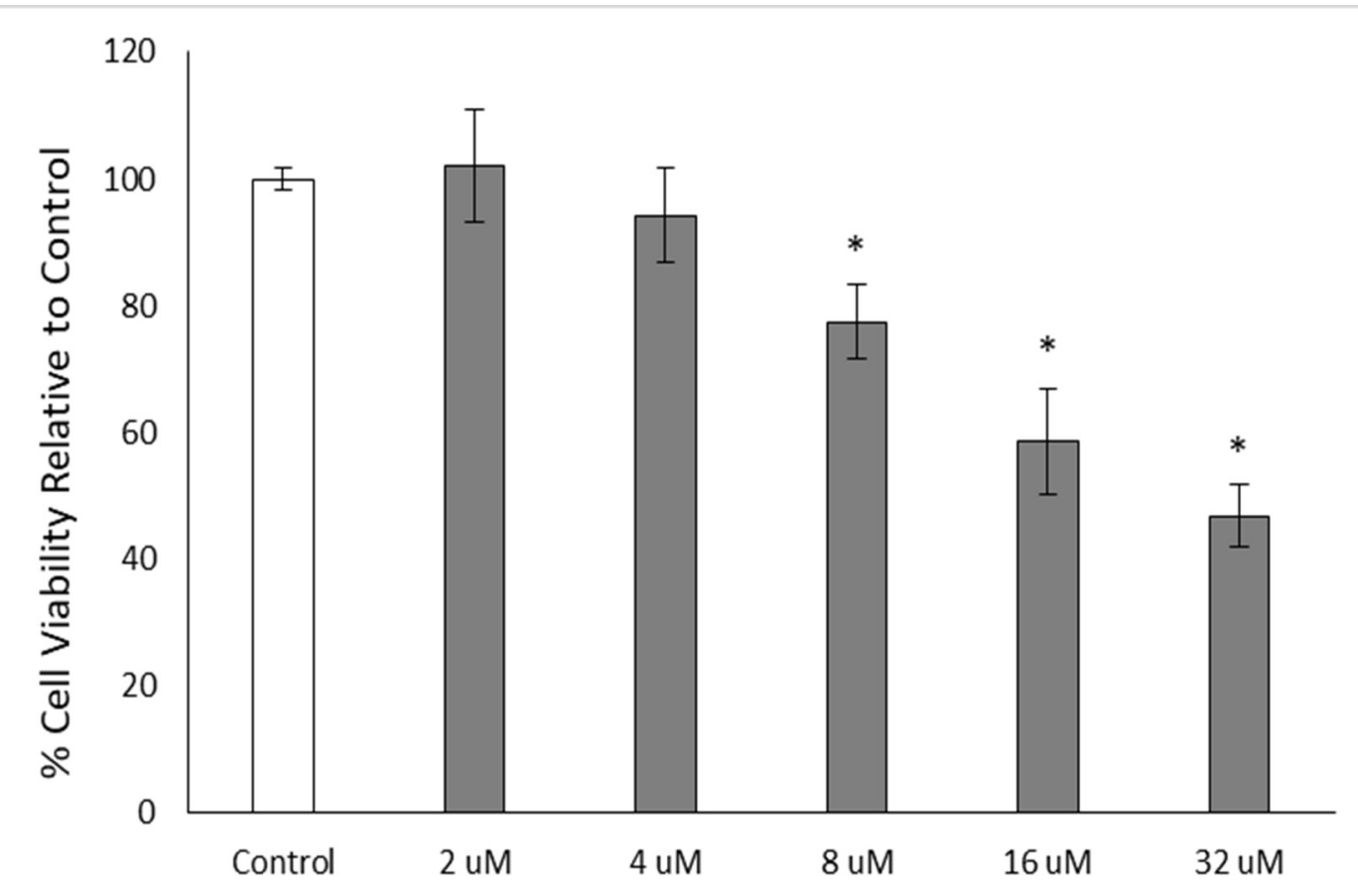

Figure 7. Viability of human RL-14 cardiac myocytes measured by an MTT assay after treatment with MyoNovin at concentrations $2,4,8,16$, and $32 \mu \mathrm{M}(0.6,1.2,2.3,4.6$, and $9.2 \mu \mathrm{g} / \mathrm{mL}$, respectively) for 24 hours ( $\mathrm{n}=4$; mean $\pm \mathrm{SEM})$ relative to untreated control. $* \mathrm{P}<0.05$ compared to control.

A

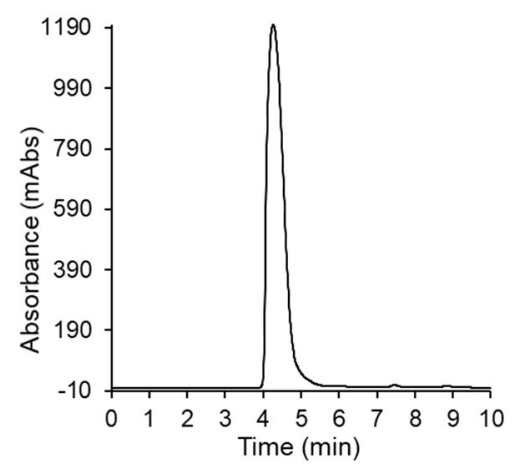

B

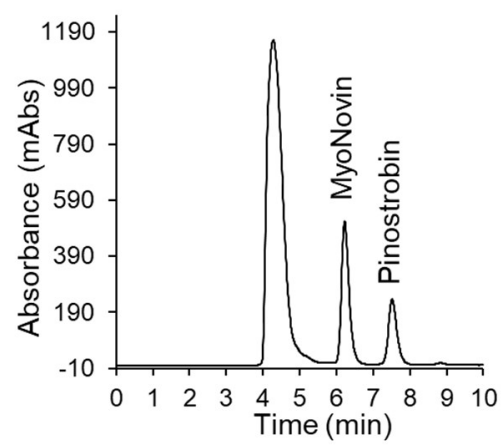

C

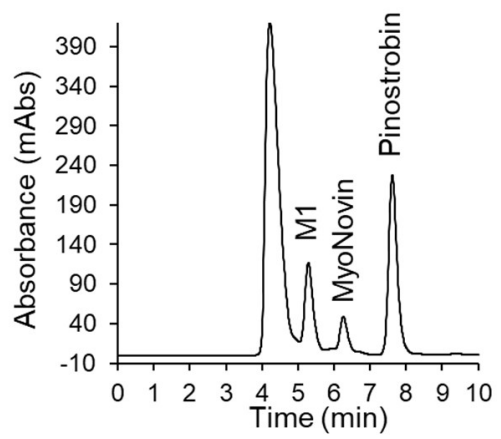

Figure 8. Representative chromatograms of (A) blank serum (B) MyoNovin $(100 \mu \mathrm{g} / \mathrm{mL})$ and pinostrobin $(10 \mu \mathrm{g} / \mathrm{mL})$ spiked in serum (C) MyoNovin, pinostrobin and M1 1 min after administration of MyoNovin (20 mg/kg) to animals.

Table 4. Accuracy and precision of MyoNovin in serum ( $\mathrm{n}=5$ days, mean \pm SEM)

\begin{tabular}{lllll}
\hline $\begin{array}{l}\text { Concentration } \\
\text { (Added) }\end{array}$ & $\begin{array}{l}\text { Average } \\
\text { (Calculated) }\end{array}$ & CV $(\%)$ & Bias $(\%)$ & Recovery (\%) \\
\hline 5 & $4.46 \pm 0.26$ & 13.21 & -10.75 & $105.16 \pm 5.8$ \\
10 & $10.56 \pm 0.21$ & 4.43 & 5.61 & $105.13 \pm 2.92$ \\
25 & $27.87 \pm 0.39$ & 3.1 & 11.47 & $99.34 \pm 4.69$ \\
50 & $53.33 \pm 0.95$ & 3.99 & 6.66 & $98.34 \pm 1.62$ \\
100 & $97.36 \pm 0.53$ & 1.22 & -2.63 & $96.9 \pm 4.12$ \\
\hline
\end{tabular}


In vivo Characterization

Disposition and Pharmacokinetics of MyoNovin after IV Administration

Following IV administration, MyoNovin was detected in serum up to 30 min post-dosing (Figure 8) with a maximum extrapolated serum concentration $\left(\mathrm{C}_{0}\right)$ of $43.6 \pm 8.8 \mu \mathrm{g} / \mathrm{mL}$. The serum disposition profile of MyoNovin showed an initial sharp decline in concentration over the first $5 \mathrm{~min}$, representing a distribution phase; this was followed by a further rapid decline over the next 15-30 min (last measurable concentration), representing an elimination phase (Figure 9). The serum concentration versus time profile followed a biexpotential pattern indicating that MyoNovin resides beyond the vasculature and penetrates into tissues. Interestingly, at 1 min post-dosing, a new peak (M1) was also observed at an earlier retention time than that of MyoNovin and was detectable for up to $1 \mathrm{~h}$. The M1 peak decreased over time, similar to that of MyoNovin, indicating that it could be a metabolite of MyoNovin formed as result of NO release in vivo. Figure 10 shows a proposed schematic for the mechanism of NO and M1 release. Figure 11 illustrates possible metabolic pathways for MyoNovin after the release of nitric oxide.

Table 5 demonstrates the pharmacokinetic parameters of MyoNovin following a single IV administration $(20 \mathrm{mg} / \mathrm{kg})$. The half-life of MyoNovin was $0.16 \mathrm{~h}$ (Table 5), suggesting that MyoNovin remained intact for a short time before rapidly undergoing metabolism, possibly after, releasing nitric oxide. The volume of distribution $\mathrm{V}_{\mathrm{ss}}$ of MyoNovin was $0.62 \pm 61.58 \mathrm{~L} / \mathrm{kg}$ suggesting that it was distributed to tissues in a manner comparable to that predicted by ADMET Predictor software (Table 3). The total clearance was $8.49 \pm 3.35 \mathrm{~L} / \mathrm{h} / \mathrm{kg}$ and $\mathrm{AUC}_{\text {inf }}$ and total body exposure was $8.13 \pm 5.23$ $\mu \mathrm{g} * \mathrm{~h} / \mathrm{mL}$.

\section{Renal Effects}

\section{Effects on urinary output}

Urinary output of rats over $24 \mathrm{~h}$ was monitored and compared before and after administration of a single IV dose of MyoNovin $(20 \mathrm{mg} / \mathrm{kg})$. There was no significant difference in total urine volume excreted pre-dose $(24.2 \pm 5.9 \mathrm{~mL})$ vs post dose $21.5 \pm 5.1 \mathrm{~mL}$.

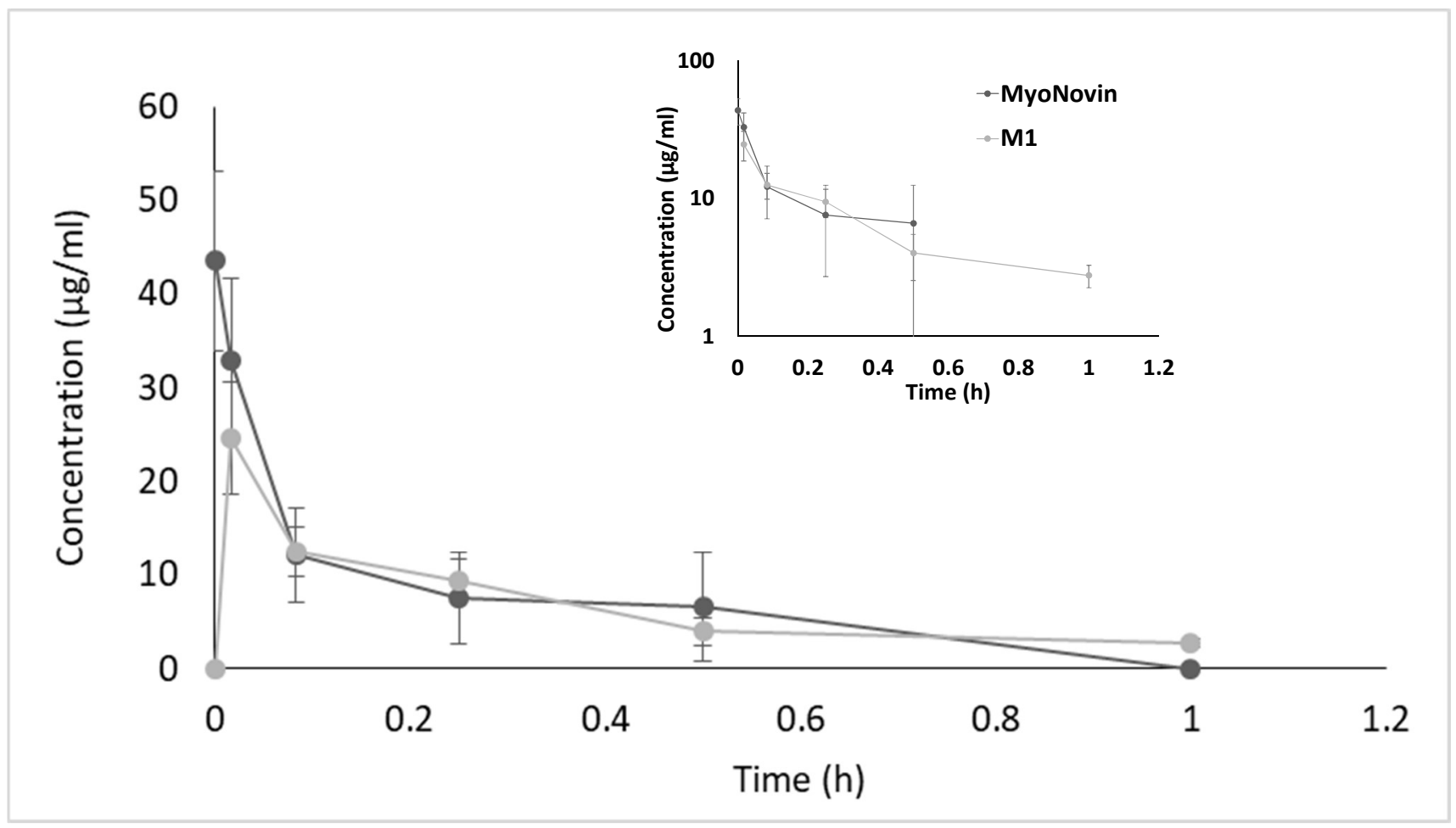

Figure 9. A graph of the serum concentration versus time for MyoNovin after IV administration $(20 \mathrm{mg} / \mathrm{kg}, \mathrm{n}=5, \mathrm{mean}$ \pm SEM). The figure insert shows the $y$-axis of the same serum concentration versus time curve on a Log scale. 
Table 5. The pharmacokinetics of MyoNovin in rat serum after IV administration $(20 \mathrm{mg} / \mathrm{kg})($ mean $\pm \mathrm{SEM}, \mathrm{n}=5$ unless otherwise stated).

\begin{tabular}{ll}
\hline Pharmacokinetic parameter & MyoNovin \\
\hline $\mathrm{C}_{0}(\mu \mathrm{g} / \mathrm{mL})$ & $43.6 \pm 8.82$ \\
$\mathrm{~K}_{\mathrm{el}}(1 / \mathrm{h})$ & $12.6 \pm 4.73$ \\
$\mathrm{t}_{1 / 2}(\mathrm{~h})$ & $0.16 \pm 0.1$ \\
$\mathrm{AUC}$ & $5.1 \pm 2.34$ \\
$\mathrm{AUC}_{\text {list }}(\mu \mathrm{g} . \mathrm{h} / \mathrm{mL})$ & $8.13 \pm 5.23$ \\
$\mathrm{~T}_{\text {last }}(\mathrm{h}){ }^{1}$ & 0.25 \\
$\mathrm{~V}_{\mathrm{ss}}(\mathrm{L} / \mathrm{kg})$ & $0.62 \pm 61.58$ \\
$\mathrm{CL}_{\text {total }}(\mathrm{L} / \mathrm{h} / \mathrm{kg})$ & $8.49 \pm 3.35$ \\
\hline
\end{tabular}<smiles>COc1ccccc1OCC(C[N+](=O)[O-])[N+](=O)[O-]</smiles><smiles>COc1ccccc1OCC(O)CO</smiles>

Figure 10. Proposed schematic representing MyoNovin biotransformation in vivo, based on reference (24).

\section{$\beta$ - $N$-Acetylglucosaminidase (NAG)}

Nitric oxide plays important physiological and pathophysiological roles in kidney function (30), and excessive NO production could induce renal toxicity (31). In addition, MyoNovin could be metabolized to beta-(2-methoxyphenoxy)-lactic acid, a compound that has been localized in the presence of kidney stones (32). Therefore, the potential renal toxicity of MyoNovin was assessed by measuring $\beta$-Nacetylglucosaminidase (NAG), a sensitive marker of kidney injury (33). Cumulative NAG excreted in urine $24 \mathrm{~h}$ post MyoNovin IV dosing $(20 \mathrm{mg} / \mathrm{kg})$ was not statistically different from the baseline control level of cumulative NAG excretion. A positivecontrol group of rats received a single IV dose of doxorubicin $(10 \mathrm{mg} / \mathrm{kg})$, a known nephrotoxic anticancer drug where there was a significant increase in cumulative urinary NAG excreted over the same period of time compared to baseline controls $(0.4$ \pm 0.17 vs $0.09 \pm 0.1)$. 


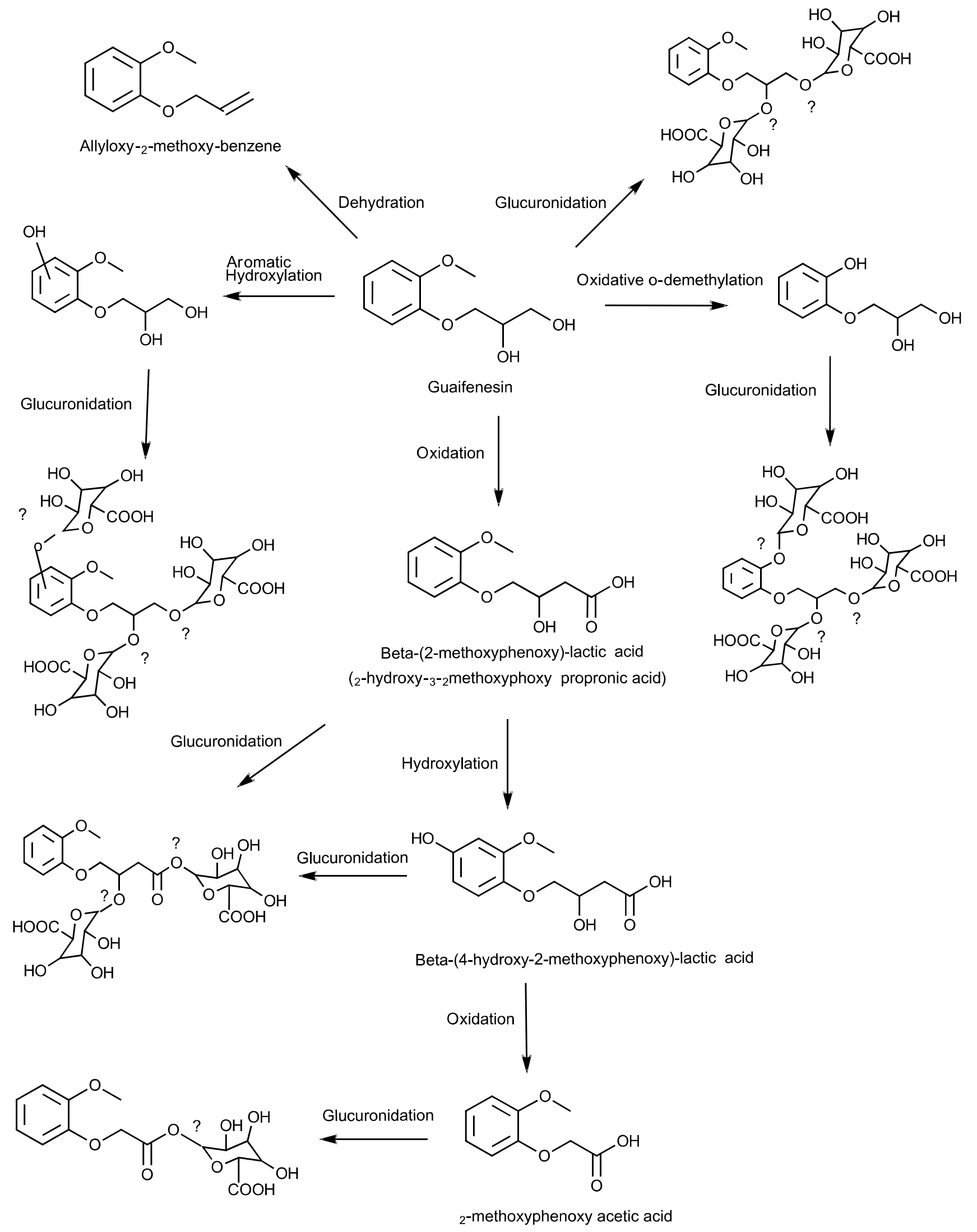

Figure 11. Schematic representation of proposed metabolic pathways for guaifenesin, based on references (25-29). 


\section{Effect on Serum Cardiac Troponin}

Nitric oxide can play protective and/or detrimental roles in cardiac function (34). The potential cardiac toxicity of MyoNovin was assessed by measuring levels of cardiac troponin (cTnI), a sensitive marker of myocardial damage (35). Cardiac Tn1 concentrations in serum samples collected $24 \mathrm{~h}$ after MyoNovin IV administration were not significantly different from baseline controls. Figure 12 shows cTn 1 concentration $24 \mathrm{~h}$ post MyoNovin $(20 \mathrm{mg} / \mathrm{kg}$ IV) compared to those $24 \mathrm{~h}$ following a single IV dose of doxorubicin. Although the concentration of cTn1 was much higher in the doxorubicin group, it was not significantly different in from the control concentration, largely due to within-group variability.

\section{DISCUSSION}

MyoNovin was designed to deliver nitric oxide to skeletal muscle, thus providing a novel drug-delivery approach by utilizing guaifenesin as a carrier for transporting NO (9). While there are no clinically viable drugs that directly initiate skeletal muscle growth and regeneration, such treatment would be beneficial in restoring muscle mass in atrophic and some disease conditions. Thus, pharmaceutical development of MyoNovin could lead to a viable pharmacological approach for the treatment of skeletal muscle atrophy associated with aging, disuse and denervation, and for the repair of skeletal muscle after injury or disease. MyoNovin is a novel drug targeted toward skeletal muscle regeneration and with potentially lower levels of systemic toxicities typically associated with conventional NO donors. As MyoNovin is an investigational compound, its physicochemical properties, biodistribution, pharmacokinetics, and safety have not yet been examined. In this report, we characterized MyoNovin in silico using computer software to explore the physiochemical and biopharmaceutical properties. We also developed and validated an HPLC assay to quantitate MyoNovin concentrations in serum following IV administration, which allowed us to elucidate initial pharmacokinetic profile.

In silico characterization of MyoNovin revealed that it has low predicted water solubility, a $\log \mathrm{P}$ of 3.5, reasonable solubility in fed-state gastrointestinal fluids, good intestinal permeability, and a low likelihood of efflux by transporters (Tables 1 and 2). These parameters suggest that MyoNovin is a potential candidate for oral administration. The fact that the solubility of MyoNovin in fed-state simulated gastrointestinal fluids is more than 30 -fold higher than in fasted-state fluids suggests that better oral absorption would be achieved when administered with food. Given that MyoNovin is a neutral compound and that its solubility is generally expected to be unaffected by fluctuations in the $\mathrm{pH}$ according to predictions by GastroPlus ${ }^{\mathrm{TM}}$ software (Figure 2A), it is possible that MyoNovin solubility would be compromised in gastric fluids, as predicted by ADMET Predictor ${ }^{\mathrm{TM}}$ software (Table 2). Further development of an oral formulation, use of an enteric coated solid-dosage form of MyoNovin or incorporation of an acid-neutralizing excipient into the formulation may be useful to overcome the limited solubility of the compound in gastric fluids. Moreover, if MyoNovin is to be administered as a liquid oral formulation, the vehicle used in that formulation may affect MyoNovin solubility in gastrointestinal fluid and also its absorption from the gastrointestinal tract. In previous studies published by our group, MyoNovin was administered as a liquid formulation in corn oil by oral gavage to mice at a dose of $80 \mathrm{mg} / \mathrm{kg}(9)$ or as a suspension in canola oil (11). Corn and canola oils may have improved the solubility of the lipophilic molecule, MyoNovin, and also may its absorption from the intestine and lymphatics. Most importantly, the oral administration of MyoNovin did result in the desired pharmacological effect in vivo, as evidenced by the increase in DNA synthesis in skeletal muscle $24 \mathrm{~h}$ post-dose (9).

Another potential route for MyoNovin administration could be transdermal. An ointment transdermal formulation of MyoNovin may be superior to an oral formulation, due to the ease of transdermal application especially in older individuals with swallowing difficulties. A potential therapeutic barrier to transdermal drug delivery is the ability of a drug to permeate across the stratum corneum layer of the skin. Prediction of MyoNovin's skin permeability by ADMET predictor ${ }^{\mathrm{TM}}$ software $\left(19.89 \mathrm{~cm} / \mathrm{s}^{*} 10^{7}\right)$ and its high lipophilicity (predicted by GastroPlus ${ }^{\mathrm{TM}} \log \mathrm{P} \sim 3.5$ ) renders it a potential candidate for transdermal application. Furthermore, the vehicle and excipients used in a transdermal ointment formulation can also have an effect on the permeability of MyoNovin through the skin. Administration of MyoNovin as a 2\% ointment formulation in Dermabase on the shaved skin on the back of mice did increase DNA synthesis of 


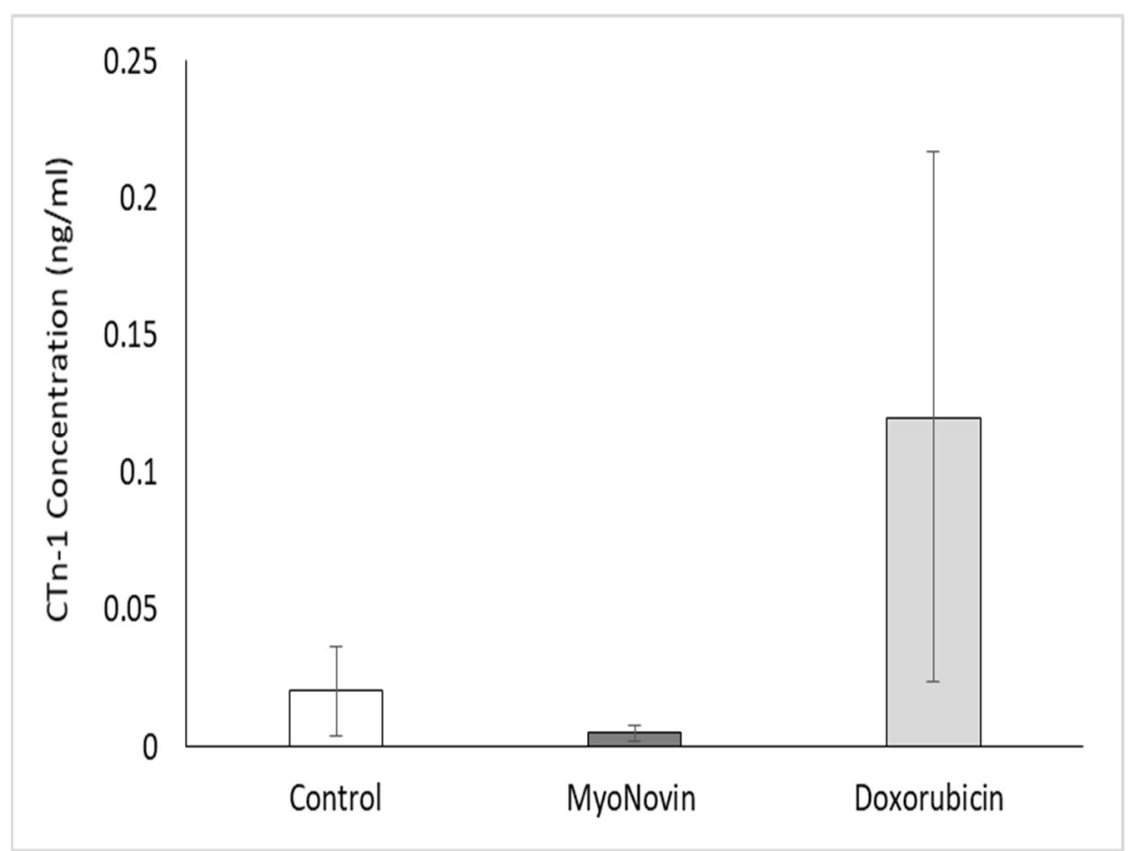

Figure 12. cTnI concentration (mean $\pm \mathrm{SEM})$ after IV administration of MyoNovin $(20 \mathrm{mg} / \mathrm{kg})$ and doxorubicin $(10 \mathrm{mg} / \mathrm{kg})$ compared to control cTnI. Control $(n=7)$, MyoNovin $(n=4)$, and doxorubicin $(n=3)$. There was no statistical difference observed among group.

skeletal muscles $24 \mathrm{~h}$ following application (9), demonstrating the feasibility of transdermal administration, although it is possible that Dermabase itself, may have improved the permeation of MyoNovin through the skin.

The effects of MyoNovin on metabolic enzymes were examined in vitro using a commercial assay kit. CYP3A4 is the major metabolic enzyme involved in first-pass metabolism. Results demonstrated that MyoNovin does not inhibit CYP3A4. This observation is also consistent with the in silico observations as predicted by ADMET Predictor ${ }^{\mathrm{TM}}$ software (Table 2). Interestingly, the same software program also predicted that MyoNovin is a substrate of CYP3A4. The high likelihood of MyoNovin as a substrate of CYP3A4 suggests that it would likely be susceptible to first-pass metabolism, which may decrease its oral bioavailability and require a higher oral dose for treatment efficacy.

To examine the disposition of MyoNovin in biological fluids and characterize its pharmacokinetics, an HPLC assay was developed and successfully applied to quantitate the concentration of MyoNovin in rat serum after IV administration. The IV route was chosen for this initial pharmacokinetic study because its pharmacokinetic parameters would not be contaminated by an absorption phase and/or first- pass metabolism that affects the outcome of drug treatment administered orally. Only male rats were used to minimize factors that may contribute to sexbased differences in metabolism and pharmacokinetics $(36,37)$. Male and female rats could metabolize MyoNovin to different extents due sex dependent hepatic metabolism. Non-metabolic sex based differences in clearance and volume of distribution are also present in animal species (38, 39) and may affect the disposition of MyoNovin. Moreover, female rats may have higher fat content (especially subcutaneous fat) due to estrogen levels $(40,41)$ and this may affect the distribution of lipophilic drugs. Sex based differences in pharmacokinetics may affect serum drug levels and thus the minimum toxic dose that could increase cardiac and renal toxicity biomarkers may be different between male and female rats in our study.

In this study, MyoNovin was detected in rat serum up to 30 min post-dose, with a biexponential disappearance from plasma. The terminal half-life was very fast, with a $t_{1 / 2}$ of $0.16 \mathrm{~h}$. The short half-life of MyoNovin may be anticipated since the compound is designed to release $\mathrm{NO}$ in vivo, leading to the formation of a new metabolite. The observed half-life of MyoNovin is close to the reported halflife of its precursor guaifenesin: $0.82 \mathrm{~h}$ in rats (42) and $1.41 \mathrm{~h}$ in ponies (43) after IV administration, and 
$0.6-1.03 \mathrm{~h}$ in humans after oral administration 44). Furthermore, detection of MyoNovin in serum for up to 30 min post-dosing as well an M1 peak suggested that MyoNovin stays intact in the systemic vasculature, releasing $\mathrm{NO}$ and distributing it to tissues before it undergoes biotransformation.

The reported physiological parameters of a 0.25 $\mathrm{kg}$ rat indicate that the total blood volume is approximately $13.5 \mathrm{~mL}$ and total body water is 167 $\mathrm{mL}$ (45), which translates to $0.054 \mathrm{~L} / \mathrm{kg}$ and 0.668 $\mathrm{L} / \mathrm{kg}$, respectively. The observed $\mathrm{V}_{\mathrm{ss}}$ of MyoNovin $(0.620 \pm 61.58 \mathrm{~L} / \mathrm{kg})$ is larger than the total blood volume and is almost equal to the total body water; these findings suggest that MyoNovin is rapidly distributed beyond the systemic circulation. The fact that MyoNovin is lipophilic (predicted Log P 3.49, Table 1) and $V_{s s}$ is not greater than total water volume suggests that MyoNovin may be distributed to tissues such as skeletal muscles. Also, the observed $\mathrm{V}_{\mathrm{ss}}$ of MyoNovin is comparable to the reported $\mathrm{V}_{\mathrm{ss}}$ values of guaifenesin, $0.79 \mathrm{~L} / \mathrm{kg}$ in rats (42), $0.79 \mathrm{~L} / \mathrm{kg}$ in horses (43), and $0.68 \mathrm{~L} / \mathrm{kg}$ in donkeys (43).

The safety of MyoNovin on cardiac muscles was examined both in vitro and in vivo. Human cardiomyocytes were cultured in vitro to assess the safety of MyoNovin on heart muscle. RL-14 cells are a commercially available cell line isolated from human ventricular tissue, and are commonly used to investigate toxic effects induced by xenobiotics. Although there were no in vivo effects of MyoNovin on cardiac size noted after 18 days of treatment in dystrophic mice (11), the effects of MyoNovin on cardiac tissue are not known in any detail. Here, cardiomyocytes were treated with MyoNovin at several concentrations, $2,4,8,16$, and $32 \mu \mathrm{M}$ to assess safety in vitro. Results demonstrated that MyoNovin did not induce significant cytotoxicity at $4 \mu \mathrm{M}$ or lower as the percent viability was about 94 $\%$ (Figure 7). However, cardiomyocytes treated with MyoNovin at $8 \mu \mathrm{M}$ showed only $77 \%$ cell viability, suggesting that MyoNovin may be cardiotoxic at concentrations at or above $8 \mu \mathrm{M}$. In this study, rats dosed with $20 \mathrm{mg} / \mathrm{kg}$ MyoNovin showed a maximum circulating concentration of $43.6 \mu \mathrm{g} / \mathrm{mL}(151.3 \mu \mathrm{M})$. Assuming linear kinetics a dose of $1 \mathrm{mg} / \mathrm{kg}$ would provide a maximum circulating serum concentration of $\sim 8 \mu \mathrm{M}(2.3 \mu \mathrm{g} / \mathrm{mL})$, which demonstrated cardiac toxicity in vitro. Despite the observed cardiotoxic effects of MyoNovin in vitro at $8 \mu \mathrm{M}$ during the 24 $\mathrm{h}$ of incubation, examination of cardiac troponin concentration $24 \mathrm{~h}$ after a single IV dose of MyoNovin $(20 \mathrm{mg} / \mathrm{kg})$ in rats showed no acute evidence of cardiotoxicity in vivo (Figure 13). Furthermore, studies of urinary output and NAG 24 $\mathrm{h}$ after administration of the same dose of MyoNovin in vivo showed no initial evidence of renal toxicity (Figure 12). Findings therefore suggest that a single IV $20 \mathrm{mg} / \mathrm{kg}$ dose did not induce acute cardiac or renal toxicity up to $24 \mathrm{~h}$ post-dosing, despite reaching a maximum circulating concentration of $43.6 \pm 8.82 \mu \mathrm{g} / \mathrm{mL}(151.3 \mu \mathrm{M})$. It is imperative to note that our in vivo results are generated only after single doses. Further research is needed to ascertain the effect of MyoNovin on cardiac cells.

\section{CONCLUSIONS}

MyoNovin is a novel synthetic skeletal muscle regenerating agent that was developed using guaifenesin as a carrier system to deliver NO to muscle. Given that there are no viable pharmacological treatments for skeletal muscle atrophy, MyoNovin and analogues we have synthesized could be a feasible therapeutic approach to restore loss of skeletal muscle mass associated with aging, or to treat diseases by promoting normal repair after injury. Use of guaifenesin's molecular skeleton in MyoNovin was intended to enhance the localization of NO to skeletal muscle, and thus lower its tendency to induce undesirable systemic effects associated with conventional NO donors.

Our preliminary in silico and in vitro observations of MyoNovin in this study, along with in vivo results from our previous reports $(9,11)$ suggest that intravenous, oral, and transdermal routes might all be feasible for MyoNovin administration. Pharmacokinetic characterization shows that MyoNovin has a short plasma half-life. Previous and current results now provide a basis for further experiments to explore dosing regimen required to achieve optimal therapeutic outcome and delineate the toxicokinetic profile of MyoNovin. In addition, efforts to study skin flux and optimize MyoNovin formulations (particularly solubility) are also warranted and are in progress in our laboratory.

\section{ACKNOWLEDGMENTS}

The authors would like to acknowledge Kuwait University, Faculty of Health Sciences, College of Pharmacy for the graduate scholarship awarded to Samaa Alrushaid. Zaid H. Maayah is the recipient of an Izaak Walton Killam Memorial Scholarship and an Alberta Innovates - Health Solution Graduate Student Scholarship. 


\section{REFERENCES}

1. Wozniak AC, Pilipowicz O, Yablonka-Reuveni Z, Greenway S, Craven S, Scott E, Anderson JE. C-Met expression and mechanical activation of satellite cells on cultured muscle fibers. J Histochem Cytochem, 2003; Nov;51(11):1437-45.

2. Darr KC, Schultz E. Exercise-induced satellite cell activation in growing and mature skeletal muscle. $\mathrm{J}$ Appl Physiol (1985). 1987 Nov;63(5):1816-21.

3. Tatsumi R, Liu X, Pulido A, Morales M, Sakata T, Dial S, Hattori A, Ikeuchi Y, Allen RE. Satellite cell activation in stretched skeletal muscle and the role of nitric oxide and hepatocyte growth factor. $A m J$ Physiol Cell Physiol, 2006; 290(6):C1487-94.

4. Wozniak, A. C.; Anderson, J. E. Single-fiber isolation and maintenance of satellite cell quiescence. Biochem. Cell Biol, 2005; 83, 674-6.

5. Anderson JE. Molecular Biology of Cell, 2000; May;11:1859-1874.

6. Miller KJ, Thaloor D, Matteson S, Pavlath GK. Hepatocyte growth factor affects satellite cell activation and differentiation in regenerating skeletal muscle. Am J Physiol Cell Physiol, 2000 ;278(1):C174-81.

7. Mauro A. Satellite cell of skeletal muscle fibers. J Biophys Biochem Cytol, 1961; 9:493-5.

8. Moss FP, Leblond CP. Satellite cells as the source of nuclei in muscles of growing rats. Anat Rec, 1971; 170(4):421-35.

9. Wang G, Burczynski FJ, Hasinoff BB, Zhang K, Lu Q, Anderson JE. Development of A Nitric Oxide Releasing Analogue of the Muscle Relaxant Guaifenesin for Skeletal Muscle Satellite Cell Myogenesis. Mol Pharm. 2009; 6(3):895-904.

10. Wang G, Burczynski FJ, Anderson JE. Composition and methods for enhancing nitric oxide delivery. U.S. Patent 8,106,080 B2 filed June 8, 2006, and issued January $31,2012$.

11. Mizunoya W, Upadhaya R, Burczynski FJ, Wang G, Anderson JE. Nitric oxide donors improve prednisone effects on muscular dystrophy in the $\mathrm{mdx}$ mouse diaphragm.Am J Physiol Cell Physiol. 2011 May;300(5):C1065-77.

12. Tetko, I.V.; Gasteiger, J.; Todeschini, R.; Mauri, A.; Livingstone, D.; Ertl, P.; Palyulin, V.A.; Radchenko, E.V.;Zefirov, N.S.; Makarenko, A.S.; et al. Virtual computational chemistry laboratory-Design and description.J. Comput. Aid. Mol. Des, 2005; 19, 453463.

13. Virtual Computational Chemistry Laboratory. Available online: http://www.vcclab.org (accessed on 24 August 2017).

14. Liu Y, Schubert D. Cytotoxic amyloid peptides inhibit cellular 3-(4,5-dimethylthiazol-2-yl)-2,5diphenyltetrazolium bromide (MTT) reduction by enhancing MTT formazan exocytosis. J Neurochem, 1997; 69(6):2285-93.

15. Maayah ZH, El Gendy MA, El-Kadi AO, Korashy HM. Sunitinib, a tyrosine kinase inhibitor, induces cytochrome P450 1A1 gene in human breast cancer MCF7 cells through ligand-independent aryl hydrocarbon receptor activation. Arch Toxicol, 2013; 87(5):847-56.

16. Lillico R, Sayre CL, Sitar DS, Davies NM, Baron CM, Lakowski TM. Quantification of cefazolin in serum and adipose tissue by ultra high performance liquid chromatography-Tandem mass spectrometry (UHPLC-MS/MS): application to a pilot study of obese women undergoing cesarean delivery. J Chromatogr B Analyt Technol Biomed Life Sci, 2016; 15;1031:94-98.

17. Charles River Laboratories International, Vascular Catheterizations:Handling Instructions, 2012.

18. Naughton, C.A. Drug-induced nephrotoxicity. Am. Fam. Physic, 2008; 78, 743-750.

19. Le, J.M.; Han, Y.H.; Choi, S.J.; Park, J.S.; Jang, J.J.; Bae, R.J.; Lee, M.J.; Kim, M.J.; Lee, Y.H.; Kim, D.; et al. Variation of nephrotoxicity biomarkers by urinary storage condition in rats. Toxicol. Res, 2014; 30, 305-309.

20. Alrushaid S, Sayre CL, Yáñez JA, Forrest ML, Senadheera SN, Burczynski FJ, Löbenberg R, Davies NM. Pharmacokinetic and Toxicodynamic Characterization of a Novel Doxorubicin Derivative. Pharmaceutics, 2017; 13;9(3).

21. www.Drugbank.ca

22. Wallace JL. Nitric oxide as a regulator of inflammatory processes. Mem Inst Oswaldo Cruz. 2005 Mar;100 Suppl 1:5-9.

23. US Food and Drug Administration Guidelines on Analytical Procedures and Methods Validation for Drugs and Biologics, US Food and Drug Administration, 2015.

24. Wong PS, Fukuto JM. Reaction of organic nitrate esters and S-nitrosothiols with reduced flavins: a possible mechanism of bioactivation. Drug Metab Dispos, 1999; 27(4):502-9.

25. Kauert G, von Meyer L, Drasch G. Investigations of guaifenesine metabolism with gas chromatographymass spectrometry. Arch Toxicol, 1980; 45(2):14959.

26. Giri SN. The pharmacological action and Odemethylation of glyceryl guaiacolate ether in male and female rats. Toxicol Appl Pharmacol, 1973;24(4):513-8.

27. Vandenheuvel WJ, Smith JL, Silber RH. -(2Methoxyphenoxy)lactic acid, the major urinary metabolite of glyceryl guaiacolate in man. J Pharm Sci, 1972; 61(12):1997-8.

28. Naito SI, Mizutani M, Kitao K, Nishimura S. Biopharmaceutical studies on guiacol glycerol ether and related compounds. 3. Metabolites of guaiacol 
glycerol ether and its mononicotinate. 1. Chem Pharm Bull (Tokyo). 1969 Sep;17(9):1794-8.

29. Mizutani M, Naito S. Studies on absorption and excretion of drugs. XXIX. Biopharmaceutical studies on guaiacol glycerol ether and related compounds. I. Blood level of guaiacol glycerol ether in rabbit and its binding with serum proteins. Chem Pharm Bull (Tokyo), 1967;15(9):1422-6.

30. Notenboom S, Miller DS, Smits P, Russel FG, Masereeuw R. Role of NO in endothelinregulated drug transport in the renal proximal tubule. Am J Physiol Renal Physiol, 2002; 282(3):F458-64.

31. Kone BC. Nitric oxide in renal health and disease. Am J Kidney Dis 30: 311-333, 1997.

32. Pickens CL, Milliron AR, Fussner AL, Dversdall BC, Langenstroer P, Ferguson S, Fu X, Schmitz FJ, Poole EC. Abuse of guaifenesin-containing medications generates an excess of a carboxylate salt of beta-(2methoxyphenoxy)-lactic acid, a guaifenesin metabolite, and results in urolithiasis. Urology, 1999; 54(1):23-7.

33. Le, J.M.; Han, Y.H.; Choi, S.J.; Park, J.S.; Jang, J.J.; Bae, R.J.; Lee, M.J.; Kim, M.J.; Lee, Y.H.; Kim, D.; et al. Variation of nephrotoxicity biomarkers by urinary storage condition in rats. Toxicol. Res, 2014; 30, 305-309.

34. Ferdinandy P, Schulz R. Nitric oxide, superoxide, and peroxynitrite in myocardial ischaemia-reperfusion injury and preconditioning. $\mathrm{Br} \mathrm{J}$ Pharmacol, 2003;138(4):532-43.

35. Adamcova, M.; Sterba, M.; Simunek, T.; Potacova, A.; Popelova, O.; Mazurova, Y.; Gersl, V. Troponin as a marker of myocardiac damage in drug-induced cardiotoxicity. Expert Opin. Drug Saf, 2005; 4, 457472.

36. Czerniak R. Gender-based differences in pharmacokinetics in laboratory animal models. Int $J$ Toxicol. 2001;20(3):161-3.
37. Lyu C, Zhang Y, Zhou W, Zhang S, Kou F, Wei H, Zhang N, Zuo Z. Gender-Dependent Pharmacokinetics of Veratramine in Rats: In Vivo and In Vitro Evidence. AAPS J. 2016;18(2):432-44.

38. Witkamp RF, Yun HI, van't Klooster GA, van Mosel JF, van Mosel M, Ensink JM, Noordhoek J, van Miert AS.Comparative aspects and sex differentiation of plasma sulfamethazine elimination and metabolite formation in rats, rabbits, dwarf goats, and cattle. $\mathrm{Am}$ $J$ Vet Res. 1992 Oct;53(10):1830-5.

39. Griffin RJ, Godfrey VB, Kim YC, Burka LT.Sexdependent differences in the disposition of 2,4dichlorophenoxyacetic acid in Sprague-Dawley rats, B6C3F1 mice, and Syrian hamsters. Drug Metab Dispos. 1997 Sep;25(9):1065-71.

40. Thibault L. Animal Models of Dietary-Induced Obesity. In Conn PM (Ed.), Animal Models for the Study of Human Disease in. Elsevier Inc., 2013.

41. Jenkins AJ. Toxicokinetics and Factors Affecting Pharmacokinetic parameters. In Karch SB (Ed.), Pharmacokinetics and Pharmacodynamics of Abused Drugs. New York: CRC Press Taylor \& Francis group, 2007.

42. Kagan L, Lavy E, Hoffman A. Effect of mode of administration on guaifenesin pharmacokinetics and expectorant action in the rat model. Pulm Pharmacol Ther, 2009; 22(3):260-5.

43. Davis LE, Wolff WA. Pharmacokinetics and metabolism of glyceryl guaiacolate in ponies. Am J Vet Res, 1970; 31(3):469-73.

44. Thompson GA, Solomon G, Albrecht HH, Reitberg DP, Guenin E. Guaifenesin Pharmacokinetics Following Single-Dose Oral Administration in Children Aged 2 to 17 Years. J Clin Pharmacol, 2016; 56(7):894-901.

45. Davies B, Morris T. Physiological parameters in laboratory animals and humans. Pharm Res, 1993; 10(7):1093-5. 